\title{
Dissension over Covid-19 in Brazilian Social Networks: Isolation, Practices and Origin of the Virus
}

\author{
Dissensos sobre Covid-19 em Redes Sociais: Isolamento, Práticas e Origem do Vírus \\ Disensos sobre Covid-19 en Redes Sociales: Aislamiento, Prácticas y Origen del Virus
}

Flaviane da Costa Oliveira ORCID: https://orcid.org/0000-0003-4409-7003 Universidade Federal do Espírito Santo, Brasil E-mail: flavianecoliveira@gmail.com

Rafael Wolter

ORCID: https://orcid.org/0000-0003-1633-2141 Universidade Federal do Espírito Santo, Brasil E-mail: rafaelpeclywolter@gmail.com

Thiago Rafael Santin

ORCID: https://orcid.org/0000-0002-1295-304X Universidade Federal do Espírito Santo, Brasil E-mail: santin.thiago@gmail.com Álvaro Peixoto

ORCID: https://orcid.org/0000-0002-1480-7919 Universidade Federal do Espírito Santo, Brasil E-mail: alvarorafael.peixoto@gmail.com

Heloisa Maria Silva e Silva Pinto ORCID: https://orcid.org/0000-0001-8352-5985 Universidade Federal do Espírito Santo, Brasil E-mail: heloisamssp@gmail.com

Ana Clara Lopes Oliveira Reis ORCID: https://orcid.org/0000-0001-5778-5054 Universidade Federal do Espírito Santo, Brasil E-mail: anaclaralor@gmail.com

Júlia Ott

ORCID: https://orcid.org/0000-0002-7669-3232 Universidade Federal do Espírito Santo, Brasil E-mail: juliaott_dutra@hotmail.com

Antonio Marcos Tosoli Gomes ORCID: https://orcid.org/0000-0003-4235-9647 Universidade do Estado do Rio de Janeiro, Brasil E-mail: mtosoli@gmail.com

\begin{abstract}
The Coronavirus disease 2019 (Covid-19) pandemic has become emergent and central to communications on social media, in which several perspectives and conceptions intertwine and oppose, sometimes creating rumors and fake news. The message flow of social media can be studied within the theoretical framework of social representations. For this purpose, 300 messages about Covid-19 were gathered: 100 of individual profiles, 100 of governments and 100 fake news. An analysis of thematic content has been conducted on the three corpora. Divergently from the other means of communication, it may be observed that the fake news results are about the Chinese origin of the virus, offer homemade advice for prevention and cure of the virus and are prone to contest social isolation. Messages from individual and governmental profiles are mostly not about the origin of the virus but provide advice on hygiene practices, garbage disposal, physical activities, psychological care and defend social isolation.
\end{abstract}

Keywords: Covid-19; Social media; Fake news; Social representations; Social psychology.

\section{Resumo}

A pandemia de Covid-19 tornou-se central nas comunicações nas redes sociais virtuais onde diversos posicionamentos e concepções se entrelaçam e se opõem por vezes formando boatos e fake news. É possível estudar as mensagens que circulam nas redes sociais dentro do quadro teórico das representações sociais. Para tal, foram coletadas 300 mensagens sobre Covid-19: 100 de perfis individuais, 100 oriundas do governo e 100 fake news. Uma análise de conteúdo temática foi realizada nos três corpora. É possível observar nos resultados que as fake news, contrariamente às outras formas de comunicação, tratam de uma origem chinesa do vírus, dão conselhos caseiros para prevenção e cura do vírus e tendem a ser contrárias ao isolamento social. As mensagens de perfis individuais e governamentais, por sua vez, 
majoritariamente não tratam da origem do vírus, aconselham práticas de higiene, descarte do lixo, atividades físicas e atendimento psicológico e defendem o isolamento social.

Palavras-chave: Covid-19; Redes sociais; Fake news; Representações sociais; Psicologia social.

\section{Resumen}

La pandemia de Covid-19 se volvió central en las comunicaciones en las redes sociales virtuales, en las que se entrelazan y oponen diferentes posicionamientos y concepciones, formando a veces rumores y fake news. Es posible estudiar los mensajes que circulan en las redes sociales dentro del marco teórico de las representaciones sociales, y para tal fin se recolectaron 300 mensajes sobre Covid-19: 100 de perfiles individuales, 100 provenientes del gobierno y 100 fake news. Se realizó un análisis de contenido temático de cada uno de los cuerpos textuales. En los resultados fue posible observar que las fakes news, a diferencia de otras formas de comunicación, se refieren al origen chino del virus, dan consejos caseros para la prevención y cura del mismo y tienden a ser contrarias al aislamiento social. Los mensajes de perfiles individuales o gubernamentales, por su parte, no abordan el origen del virus, sino que recomiendan prácticas de higiene, tratamiento de la basura, actividades físicas, atención psicológica y defienden el aislamiento social.

Palabras clave: Covid-19; Redes sociales; Fake news; Representaciones sociales; Psicología social.

\section{Introduction}

The impacts caused by the pandemic go beyond health issues and strike the economic and social life of countries (Nicola et al., 2020), due to the social isolation policies adopted, which have the role of main disease containment measure. Official institutions, such as WHO and Health Ministry, also indicate the need of protective measures that have been changing throughout the pandemic, for instance the use of masks, which was not advised at the beginning and later was considered necessary.

This reality incited the political narratives dispute, which was already present before the pandemic, and, as an important part of this dispute happens in the social media field, the scenario becomes prone for the sharing of false information about the virus and the pandemic reality. In conclusion, the context is appropriate to the emergence and diffusion of fake news (Hellewell et al., 2020).

The pandemic of Covid-19 brought along an "infodemic", as said by WHO director-general to describe the misinformation situation, caused mostly by the fake news dissemination (Zarocostas, 2020). The fake news concept has been identified and labelled through the release of false messages that looked like news in the presidential campaign in the United States of America in 2016 (Mukerji, 2018).

They can be defined as a kind of misinformation, with three characteristics: it is presented in news format, usually it leads to false information, and it is projected to be phony (Gelfert, 2018). On the Covid-19 pandemic context, there are international reports of xenophobia promotion because of fake news (Shimizu, 2020), group identity use previously investigated (Schultz, Wirth \& Müller, 2020), as well as classification of its types in the Brazilian context for inquiry of the impact on sanitary policies execution and on treatment adherence (Neto et al., 2020).

Fake news has been in the spotlight in the past few years and its happening has been attached to the popularization and intensification of the use of social media. However, some of its characteristics have been widely investigated throughout the 20th century on the field of Social Psychology of communication (social representations and rumors). Since its early days, this research field has been interested in how people communicate in crisis times. From the works of Allport and Postman (1944), it has been possible to understand that people embrace shady news when they fit their pre-existing thoughts and can provide explanation to what is happening at the moment in a simplified way.

The works of Rouquette (1994) depict that social representations have an essential role on the spread of rumors and conspiracy theories. The processes of reduction, transformation and accentuation of rumor content when transmitted, described by Allport and Postman (1944), are done, according to Rouquette (1994), under the coordination of the social representations (Moscovici, 1961/2012; Sá, 1996) of the group.

The Covid-19 pandemic is a very favorable scenario to rumor and fake news dissemination, once the strong wave of 
anxiety and fear lived by the population promotes the dissemination and adhesion as much to messages whose source is not verifiable, as to those that are produced with the intention of spreading false messages. This situation brings about practical consequences to everyday life of individuals and groups. In this sense, the psychosocial aspects of the fake news phenomenon in the widest scope of individual communication may contribute to the pandemic combat.

Hence, this research aimed at identifying and comparing contents of three modes of communication in the online environment of social networks: from individual and official institutional/governmental profiles and fake news publications.

\section{Methodology}

The methodology addresses documental research with a qualitative character about aspects of communication in the online environment concerning the Covid-19 pandemic. Since it involves public data, the investigation has dismissed the Ethics and Research Committee (CEP) approval and acts accordingly to the Resolution 510/2016 of the Brazilian National Health Council.

\section{Data Source}

The research corpus has been composed of 300 posts that are on virtual social network and have been published by individuals or official profiles, according to the distribution presented on Table 1:

Table 1. Post distribution by social network and type of communication.

\begin{tabular}{lcccc}
\hline Social network & $\begin{array}{c}\text { Individual profiles } \\
\text { communication }\end{array}$ & $\begin{array}{c}\text { Official } \\
\text { communication }\end{array}$ & Fake news & Total \\
\hline Facebook & 34 & 33 & 53 & 120 \\
Instagram & 33 & 33 & 5 & 71 \\
Twitter & 33 & 34 & 28 & 95 \\
Indefinite & 0 & 0 & 14 & 14 \\
General total & 100 & 100 & 100 & 300 \\
\hline
\end{tabular}

Source: Authors.

The set of publications named individual profiles communication presents spontaneous posts (texts, images, weblinks) from individuals in social media, which may reflect personal opinion or replicate content from others (official information, scientific information, rumors etc.). Official communication is composed of posts that are intentionally spread by official institutions (in the municipal and state scope present in Espírito Santo/Brazil; political or health institutions in the federal scope and the World Health Organization). Finally, the fake news set expresses popular communication disproved, in other words, verified messages that are identified as false by fact checking agencies. During the research the profiles which have published the messages were kept anonymous, with the content being treated only in terms of these three sets.

The social media networks, Facebook, Instagram and Twitter, have been selected for presenting a large number of users in Brazil. They figure in the six most used social network according to a survey done in January 2020 (We Are Social \& Hootsuite, 2020). Also, they allow public access to the content published by its users. The cases that were not possible to determine the virtual social media were obtained directly from social media posts published in websites of fake news verification agencies.

\section{Data Gathering}

The posts that form the corpus have been obtained in social media and fact checking websites agencies in April 2020. In this research, videos, sound files and repeated messages were excluded from the data gathering. To avoid data bias in the 
official communication case, number case reports and descriptive messages about public institutions actions during the pandemic were excluded because of their repetition. The corpus was gathered by convenience until the total of messages in table 1 had been composed.

\section{Content Analysis}

The content analysis gathers a wide set of techniques and systematization and interpretation processes developed throughout the 20th century in the human and social sciences scope. It may include quantitative and qualitative analytical resources (Bardin, 2011). Therefore, "on the social sciences quantity/quality division, the content analysis is a hybrid technique that may mediate this unproductive discussion over virtues and methods" (Bauer, 2003, p. 190).

At the beginning of the 21st century, Bauer (2003) identified renewed interest in the method and mentions authors' efforts in amplifying content analysis techniques, including visual aspects. This work is inserted in this set of studies, aiming at adding text and image elements to the proposed analysis, which is imperative before the diversity of publication formats in the virtual environment.

At first, the posts were gathered and fully transcribed. Following Bardin (2011), a pre-analysis of the material was made from the reading of the data set. Each post consisted in a context unit, able to provide complementary elements for the reading of the registry units (what is encoded or counted). Among the different possibilities of content analysis, it has been applied the category or theme content analysis, so it has been chosen to adopt the "theme" as registry unit, from the record of phrases, fragments of text or iconographic aspects, which was categorized afterwards.

The categorization process involves a continuous classification and grouping of recorded elements, executed from the comparison of similarities or previous criteria (Bardin, 2011). As highlighted by Bardin (2011, p. 148), such operation involves "inventory" and "classification", meaning that elements are isolated to be, then, organized. This research did not propose previous categories for the categorization, the themes were obtained after consecutive grouping or by "archive" (p. 149). In our proposal, one context unit may present more than one thematic category and in many cases there are complementary elements. The content analysis not only sought summarizing content but also proposed inferences from the communication characteristics and the theoretical field.

\section{Results}

The categorization process consisted in the reading and the progressive classification of the registry units (registry of phrases, fragments of texts or iconographic aspects). After consecutive grouping, it resulted in fifteen thematic categories. Each of them reveals aspects about people and official institutions communication about the origin and the impacts of the virus, as well as the everyday practices related to it, in either the individual or the collective scope.

Six of the fifteen thematic categories indicate criticism or defense of public characters (media, politicians and individuals) or of measures concerning social isolation - it was sometimes considered necessary and urgent to minimize the spread of the virus, sometimes seen as exaggerated or inefficient. Besides, some publications questioned the severity of the disease and they are associated to critical messages related to the social isolation. The other categories aim at communicating elements related to the virus, its origin, circulation dynamic, symptoms, number of incidences, combat and care measures, either from scientific knowledge or from popular recipes and explanations.

The thematic categories have been quantified and the occurrences separated by type of communication (individual, official or fake news). Some category sets presented lexical proximity, offering similar meanings to the phenomenon described, which allowed the regrouping in five axes or meta-themes. Table 1 quantifies the frequency of the thematic categories and organize them in relation to the meta-themes: 
Table 2. Meta-themes and thematic categories, by type of communication.

\begin{tabular}{lccccc}
\hline Meta-theme & Thematic categories & Individual & Official & $\begin{array}{c}\text { Fake } \\
\text { news }\end{array}$ & Total \\
\hline \multirow{3}{*}{ Political scope (F=73) } & Criticism towards politicians/rulers & 12 & 0 & 10 & 22 \\
& The communist plan and the virus' origin & 10 & 0 & $19^{*}$ & 29 \\
& Politicians and State defense & 6 & 4 & 12 & 22 \\
\hline \multirow{3}{*}{ Health information } & Elderly, risk groups and solidarity & 7 & 18 & 2 & 27 \\
(F=161) & Data on virus, symptoms and cases & $30^{*}$ & 24 & 15 & 69 \\
& Precautions at home and when leaving & 7 & $46^{*}$ & 1 & 54 \\
& Physical and mental health & 3 & 8 & 0 & 11 \\
\hline Social isolation support & Criticism towards people & 12 & 0 & 2 & 14 \\
(F=102) & Social isolation defense & $31^{*}$ & $50^{*}$ & 7 & 88 \\
\hline \multirow{2}{*}{ Faith and homemade } & Medication/Cure/Vaccine & 7 & 1 & 14 & 22 \\
recipes (F=44) & Faith against the virus & 4 & 0 & 3 & 7 \\
& Homemade recipes & 0 & 0 & $15^{* *}$ & 15 \\
\hline \multirow{3}{*}{$\begin{array}{l}\text { Pandemic severity } \\
\text { relativization (F=67) }\end{array}$} & Criticism against the media & 4 & 0 & 12 & 16 \\
& Criticism against horizontal isolation and economical & 8 & 0 & $21^{*}$ & 29 \\
& crisis & 8 & 0 & 14 & 22 \\
\hline TOTAL & Doubt/uncertainty and pandemic relativization & 1 & 0 & 6 & 7 \\
\hline
\end{tabular}

Notes: *The signed numbers correspond to the highest frequencies in each case.

**Indicates the category that is only in the fake news type.

*** Banks and costs of coronavirus combat; basic food basket donations provided by supermarket chains; reflections upon human needs and limitations; understanding attitude before uncertainty; research links coronavirus and men's infertility; impossibility in using electoral fund; child registered under the name of "alquingel" (a very informal way of speaking of hand sanitizer).

Source: Authors.

The total number of incidences on table 2 is bigger than the total of items by communication type (100 posts), because each context unit may contain more than one related thematic category.

\section{Individual Profiles Communication}

The communications of individual profiles were spontaneously shared in pairs through social media. In this type, fourteen thematic categories are triggered, but only five present frequency of ten or more. Two of them with less significance are attached to the meta-theme "Political Scope", being: "Criticism against politicians/rulers" (F=12) and "The communist plan and the virus' origin" $(\mathrm{F}=10)$. These thematic categories present criticism against rulers' measures and behavior and to politicians both from the past and present, as well as some explanatory theories regarding the virus origin.

More frequently, these messages relate to two other meta-themes, Health Information and Social Isolation Support. First, Health Information contains the category "Data on virus, symptoms and cases", with technical information about the virus, symptoms, cases, deaths, flattening of contamination curve and the severity of the pandemic, reporting the local situation and also comparing it to other countries and regions. The communications in this category present information as technical-scientific and intend some neutrality, but does not inform the data source in many cases. The following fragments illustrate this category:

“How long does coronavirus live?” (Facebook - Individual profile1)

"The ones who died of \#coronavirus are being buried in muddy trenches in New York" (Instagram - Individual profile)

"7 Cases of Covid-19 in Colatina in around 1.5 weeks" (Twitter - Individual profile) 
In relation to the second meta-theme, "Social isolation support", the most common category of this type of communication are "Social isolation defense" $(\mathrm{F}=13)$ and "Criticism towards people" $(\mathrm{F}=12)$. These two categories work in a complementary manner: the first one presents and comments the social rule "Stay home" in prescriptive messages, asking people to stay home during the pandemic. The second one criticizes people who disrespect this recommendation, as we can see in these fragments:

"If we don't reach 70\% of isolation, we will be 180 thousand contaminated in 30 days." (Facebook - Individual Profile)

"Nobody knows who is healthy and who can infect you. Do you understand why it is important to stay home? Be responsible! Stay home.” (Facebook - Individual Profile)

"I still can't accept that there are people who think this pandemic is a joke and keeps going out for no important reason" (Twitter - Individual Profile).

Widely saying, the individual profiles communications reflect attempts of technical-scientific validation of arguments that support the social isolation rule as a way out of the pandemic. The individuals describe data about how the virus behaves in the organism and what are the individual and collective impacts, acknowledging its significance and defending prevention. As an attempt to build its knowledge regarding the pandemic, the scientific field still arises as an important communication element that does not address to a specific public but spreads universal knowledge with the intention of affecting both individuals and collectivity.

\section{Official Communication}

The official communications have similarities to the communications of individual profiles, but they make some contents even more salient. The communication type mentions seven thematic categories, but only four have more than 10 occurrences. All of them links to the same meta-themes presented on the previous type, "Health information" and "Social isolation support". Nevertheless, there are relevant differences on the distribution of frequencies among the most recurrent categories.

The only thematic category present in the "Social isolation support" meta-theme is "Social isolation defense" (F=50), but in this case it is not followed by "Criticism against people", but by imperative forms related to the prescriptive social norm of social isolation. Frequently this prescription is expressed in hashtags (\#) such as \#StayHome. These expressions appear around eight times more $(\mathrm{F}=152)$ in this type than in the two other types of communication (Individual, $\mathrm{F}=19 ; \mathrm{Fake}$ news, $\mathrm{F}=17$ ).

\footnotetext{
"enjoy the holiday with your family at home" (Facebook - Official)

“DO NOT LEAVE YOUR HOME” (Instagram - Official)

"YOUNG PEOPLE ARE NOT IMMUNE TO THE VIRUS” (Instagram - Official)
}

Regarding the meta-theme "Health Information", besides the category "Data on virus, symptoms and cases" (F=24), it is also contains the category "Elderly, risk groups and solidarity" (F=18) and expressively, "Precautions at home and when leaving" ( $\mathrm{F}=46)$. Besides the interest on the virus, number of cases, symptoms and severity, there are also messages proposing practices to deal with the pandemic in everyday life. Here are some of the registry units related to this last category:

"when using a homemade mask, it is necessary to have some precautions" (Facebook - Official)

"Keep some distance"; "Wash your hands" (Facebook - Official) 
"To reduce the use of cash and consequently the risk of contamination by the new Coronavirus (Covid-19) within the Transcol System [bus transport system] use the GVCard [bus ticket card].” (Instagram - Official)

"PRECAUTIONS AT THE SUPERMARKET" (Twitter - Official)

The official communications prioritize social practices to be adopted during the pandemic. They affirm the social isolation norm and exhibit some concern in guiding the population behaviors during the quarantine, either in a private or in a public environment.

\section{Fake News}

The fake news communication type also has its basis on fourteen thematic categories, just as the individual profiles communications type (rumors). However, the occurrences are distributed among the categories where nine present a frequency of ten or more, and only one reaches the maximum frequency of twenty-one. Although the number of occurrences is similarly among the different types of communication (Individual profiles=150; Official=151; Fake news=153), the frequency of this theme is scattered. The bigger difference from the other two types (individual and official) is that their three less triggered metathemes are the most expressive on this type: "Political scope", "Faith and homemade recipes" and "Pandemic severity relativization". 
Table 3. Thematic categories $(\mathrm{F} \geq 10)$ and meta-themes present in fake news.

\begin{tabular}{|c|c|c|}
\hline Meta- & Thematic category & Registry units \\
\hline \multirow{3}{*}{$\begin{array}{l}\text { Political } \\
\text { scope }\end{array}$} & $\begin{array}{l}\text { Criticism against } \\
\text { politicians/rulers } \\
\qquad(\mathrm{F}=10)\end{array}$ & $\begin{array}{c}\text { "Dória the TRAITOR: he has given a party at his girlfriend's ranch in Araçatuba." } \\
\text { (Facebook - Fake News) } \\
\text { "coronavirus did not make workers sick but has made 'mayors and governors' mad } \\
\text { and insane". (Twitter - Fake News). }\end{array}$ \\
\hline & $\begin{array}{l}\text { The communist } \\
\text { plan and the virus' } \\
\text { origin }(\mathrm{F}=19)\end{array}$ & $\begin{array}{c}\text { "in the Gemini year (2020) there will be a queen (corona-crown) from the East } \\
\text { (China)" (Facebook - Fake News) } \\
\text { "FBI has removed all masks coming from China and they have tested positive to } \\
\text { Covid-19" (Instagram - Fake News). }\end{array}$ \\
\hline & $\begin{array}{l}\text { Politician and State } \\
\text { defense }(\mathrm{F}=12)\end{array}$ & $\begin{array}{c}\text { "World Bank classifies Brazil as the best country combating Covid-19"(Facebook - } \\
\text { Fake News) } \\
\text { "President Jair Bolsonaro issued public health emergency due to Coronavirus } \\
\text { (Covid-19), } 18 \text { days before Carnival" (Facebook - Fake News) }\end{array}$ \\
\hline $\begin{array}{l}\text { Health } \\
\text { information }\end{array}$ & $\begin{array}{l}\text { Data on virus, } \\
\text { symptoms and } \\
\text { cases }(\mathrm{F}=15)\end{array}$ & $\begin{array}{l}\text { "The saddest day in Italy has been today: } 793 \text { deaths, being } 232 \text { children" } \\
\text { (Facebook - Fake News) } \\
\text { "Switzerland may be the only country in the world getting coronavirus combat } \\
\text { right." (Facebook - Fake News) }\end{array}$ \\
\hline \multirow{2}{*}{$\begin{array}{l}\text { Faith and } \\
\text { homemade } \\
\text { recipes }\end{array}$} & $\begin{array}{l}\text { Medication/Cure/ } \\
\text { Vaccine }(\mathrm{F}=14)\end{array}$ & $\begin{array}{l}\text { "BREAKING NEWS: Chinese Defense Ministry has officially announced that they } \\
\text { have successfully developed vaccine against Coronavirus."(Facebook - Fake News) } \\
\text { "research prove that hydroxychloroquine kills the virus." (Facebook - Fake News) }\end{array}$ \\
\hline & $\begin{array}{l}\text { Homemade recipes } \\
\qquad(\mathrm{F}=15)\end{array}$ & $\begin{array}{c}\text { "DO SELF BLOOD THERAPY"(Facebook - Fake News) } \\
\text { "Slices of lime and a glass of warm water can save your life" (Facebook - Fake } \\
\text { News) }\end{array}$ \\
\hline \multirow{4}{*}{$\begin{array}{l}\text { Relativization } \\
\text { of pandemic } \\
\text { severity }\end{array}$} & $\begin{array}{l}\text { Criticism against } \\
\text { the media }(\mathrm{F}=12)\end{array}$ & $\begin{array}{c}\text { "If the press releases the cure, the hysteria and audience will be over" (Facebook - } \\
\text { Fake News) } \\
\text { "Then Globo wants to criticize Bolsonaro (...) \#globotrash"(Facebook - Fake } \\
\text { News) }\end{array}$ \\
\hline & $\begin{array}{l}\text { Criticism against } \\
\text { horizontal isolation } \\
\text { and economical } \\
\text { crisis }(\mathrm{F}=21)\end{array}$ & $\begin{array}{c}\text { "It has started, and the unemployment rates haven't even risen yet! They will make } \\
\text { a chaos scenario" (Facebook - Fake News) } \\
\text { "Isolation Can Worsen The Situation, Say Harvard Researchers" (Facebook - Fake } \\
\text { News) }\end{array}$ \\
\hline & $\begin{array}{l}\text { Doubt / uncertainty } \\
\text { and pandemic }\end{array}$ & $\begin{array}{c}\text { "he died changing the truck's tire and the tire blew up on his face. The death } \\
\text { certificate said it was covid-19" (Twitter - Fake News) }\end{array}$ \\
\hline & $\begin{array}{l}\text { relativization } \\
(\mathrm{F}=14)\end{array}$ & $\begin{array}{c}\text { "new SUS* software, to register if the patient has symptoms of Covid19, does not } \\
\text { accept to register NO" (Twitter - Fake News) }\end{array}$ \\
\hline
\end{tabular}

Note: *SUS - Brazilian system of public health

Source: Authors.

As indicated in Table 3, the only thematic category related to the meta-theme "Health information" with frequency above 10 refers to "Data on virus, symptoms and cases" $(\mathrm{F}=15)$. Yet, different from the previous cases, the registry units reveal fake or inaccurate data.

The meta-theme "Political scope" was mentioned with less relevance in individual communications and here expresses "Criticism towards politicians/rulers" $(\mathrm{F}=10)$ and "Defense of politician and State" ( $\mathrm{F}=12)$. This second category reveals association between the defense of the medication chloroquine or hydroxychloroquine with the president's defense. The political scope is more often used to explain the origin of the virus, from "The communist plan and the virus origin" $(\mathrm{F}=19)$. The virus is presented here as part of a domination plan coming from China, more than from technical-scientific arguments.

In the meta-theme "Faith and homemade recipes" two thematic categories reveal search for substances that prevent or heal Covid-19. In "Medication/Cure/Vaccine" $(\mathrm{F}=14)$ the recipes indicate healing properties in substances that are pharmacologically known or indicate that "scientists" would be involved in the cure, vaccine or medication researched. "Homemade recipes" $(\mathrm{F}=15)$ are not about pharmacologically known active principles, but tea or food recipes with properties to combat Covid-19.

The meta-theme "Pandemic severity relativization" gathers three categories that question the real severity of the 
pandemic, criticizing the media coverage, depicted as sensationalist, and the social isolation measures (horizontal), as exaggerated and individual freedom restrictive. "Criticism towards horizontal isolation and economical crisis" ( $\mathrm{F}=21)$ is the most frequent in this type of communication, indicating the isolation measures as the economical crisis driver, which will be responsible for a chaos scenario.

The three meta-themes together exhibit ideas that do not have scientific data as main elements, proposing other explanations to the origin of the virus and prescribing remedies able to combat or cure it. Even though the individual profiles communication and fake news have a similar provider (anonymous), they diverge in relation to their content and format. The individual and official communications present opposite meanings to fake news, regarding origins and practices related to Covid19.

\section{Discussion}

The Covid-19 scenario imposes sanitary, economical and psychosocial consequences. When facing a threatening event, individuals and groups seek ways of understanding and dealing with the new reality. Such knowledge, built by social groups, is traditionally studied in the social psychology field, starting from the social representations field (Moscovici, 2012; 2009) and from the study of rumors (Allport \& Postman, 1945; Rouquette, 1998). Social representations may contribute to rumor spreading once they are reference to its adaptation, meaning that for the rumor to proceed in communication, it needs to adequate to the social thinking of groups about the object (Rouquette, 1994; 1998).

A social representation, as image and language structure, is built when meanings, opinions, beliefs, or images that are accessible by the group are not efficient anymore to communicate or relate to the object. This way, to "reduce tension and unbalance together, it is necessary to have the unfamiliar content to be reallocated to a content belonging to our universe" (Moscovici, 2012, p. 55). The analyzed data shows means found by internet user to deal with the pandemic, once they needed to find answers to questions about its origin, individual and collective effects and social practices to be adopted.

Among individual publications (individual and fake news) it is possible to see the effort to explain the origin of the virus. The most frequent theory connects the virus to a communist domination plan, coming from China. When finding the territory or context of creation/emergence of the virus, there are operation group stereotypes and differentiation, emphasizing the evaluative function of social representations (Guimelli, 2003). Besides measuring the risk and proximity of the object, such popular theory allows the user to create hypothesis about modes of its dissemination and "the ones to blame" for this process, who end up suffering with criminalization and discrimination. This is exemplified by the fact that masks and materials coming from China became object of suspect and threat. The virus is, then, focused and linked to material elements of social reality (Moscovici, 2009).

According to posts on the political plan of influence and domination coming from abroad, the virus would have been created as a biological weapon to bring about sanitary and economical difficulties to other countries. Therefore, the conflicts based on the Cold War past are revisited, resuming a dispute between capitalists and communists (Moscovici, 2009). The communism danger would come from China, but would already be finding intern allies, such as state governors and mayors who are favorable to social isolation. In this logic, these local authorities action emerges as influenced by the plan and consecutively their actions against the pandemic can be questioned or relativized.

In the sociogenic processes of social representations, the gaps presented by the knowledge spread in the groups are filled with information related to different forms of knowledge, such as scientific, religious, mediatic etc. When facing this theory for the cause of the virus, it is seen that scientific knowledge is not the main base for building fake news. It is not about the exchange of knowledge between the reified universe (scientific) and the consensual one (common sense), as in the seminal study of Moscovici (2012). What is at stake are rumors of great significance in the virtual environment and fallacious content. 
As a simplified form of communication, rumors suffer with losses and distortions, do not present verifiable sources and touch the individual experience by relating to important objects which demand control (Rouquette, 1975; 1991). Social representation as a structured knowledge for a social group, adds rumor, which, besides unverifiable sources, also reveals fake or imprecise information, the so called fake news, which is produced with the aim of misleading and ends up fomenting discrimination processes.

Similarly, concerning social practices related to the new Coronavirus, there is the shock between scientific knowledge and non-proven knowledge. In individual profiles communications and official communications, there is great concern with scientifically validated data on virus operation in organism and symptoms, prevention methods, number of cases, statistic models that justify the quarantine and the severity of the pandemic etc. Among the fake news, the most frequent thematic categories relate to prescriptions that do not have scientific proof or that still demand studies, such as vaccine and medication. Yet, even among the fake news, communication is done as to convince, using names or references to the science universe, even if to recommend practices with no proof, such as teas and prevention habits.

The individual profiles communication aligns mostly to the official one in the recommendations related to social isolation, which is the last contrast point with fake news. In broad terms, when building a practical theory able to face the pandemic dangers, using recipes that cure, social isolation begins to be seen as unnecessary or exaggerated. Table 4 organizes the elements that differentiate the types of communication.

Table 4. Causes, practices and social isolation, from communication types.

\section{Communication types}

Individual and official profiles communication

Unsure

Cleaning (hands, foods, clothes, home); Mask (how to make it, put it on, pack it, wash it); Trash

Practices disposal. Physical activities, psychological service (remote).

Favorable (statistic models indicate adoption as

Social alternative to decrease contamination and flatten the pandemic evolution curve)
Chinese communist plan

Fake news

Homemade recipes to prevent/protect against contamination, immune system strengthening, selfassessment. Use of pharmacological substances that need studies on virus combat.

Contrary (claim political influence in choosing horizontal isolation that restrain freedom and causes economical crisis)

Source: Authors.

Therefore, it is possible to suppose that more than one social representation is spread on the online environment, considering knowledge structures that used to measure the relation of individuals towards the object and the other, and that define differentiated social practices for the social groups. The social representations in the virtual environment, also known as "cyber representation" (Moscovici, as cited in Casalegno, 2006, p. 77), are made from fully virtual social bonds, once most of the times the groups have no other belonging and communication form, but their own representation. This process, although brief, makes it evident the identity role of representations, pushing away the risk and guiding the action.

In the cyberculture, the quantity of "hovering ideas" over a theme is immense, demanding the subjects to have a complex cognitive work to "integrate them in a coherent picture". On the other hand, when socialized in social media, the reconstructed information immediately returns to its original source, transforming not only its content, but also its language by the possibilities of co-construction that these media offer. By this view, the cyberculture is full of amateur wise ones, who "research", discuss and formulate "theories" (Mazzotti \& Campos, 2011, p. 472). 


\section{Conclusion}

Facing an almost unknown phenomenon that has caused a fast change in everyday routines such as the Covid-19 pandemic, social groups seek context interpretation and building of new knowledge to guide social practices and minimize insecurity or threat before the new social object. Virtual social network becomes stage for the spread, updating and redefinition of this object. The posts flow appears as an inciting element of social groups, bringing attention to the impact of fake news, a phenomenon born on social media, but expanding its influence over the offline world, changing the prescriptions that refer to prevention and combat of pandemic propagation.

Social networks have a central role in the dissemination of information and practices about Covid-19 prevention in Brazil. Many posts are fake news because they not checked and contain false information about the disease and its prevention methods. These fake news influence groups acting on society and their impact goes further than the virtual domain. We suggest further research to measure the impact of the fake news on the social and political domains of social life. To diminish these negative effects it is necessary to comprehend what are fake news, how they are developed and how to promote actions to prevent them. This study aimed to analyze the content of different types of social publications in order to identify how Covid-19 information is shared in social networks and to contribute to enhance the understanding of the fake news phenomenon. It is necessary to develop new methods of fake news identification as well as educational projects for students and campaigns for the population in general, which require a better articulation of fake news knowledge and other publications.

\section{Acknowledgments}

This study was partially financed by the Fundação de Amparo à Pesquisa e Inovação do Estado do Espírito Santo (FAPES) through a PhD grant for Álvaro Peixoto.

This study was also partially financed by the Coordenação de Aperfeiçoamento de Pessoal de Nível Superior - Brasil (CAPES) - Finance Code 001 through a PhD grant for Thiago Rafael Santin.

Júlia Ott had an undergraduate scientific grant (PIBIC) financed by the Conselho Nacional de Desenvolvimento Científico e Tecnológico $(\mathrm{CNPq})$ - Brasil.

\section{References}

Allport, G. W., \& Postman, L. J. (1945). Section of psychology: The basic psychology of rumor. Transactions of the New York Academy of Sciences, 8, 61-81. https://doi.org/10.1111/j.2164-0947.1945.tb00216.x.

Bardin, L. (2011). Análise de conteúdo. Edições 70.

Bauer, M. W. (2008). Análise de conteúdo clássica: Uma revisão. In M. W. Bauer \& G. Gaskell (Eds.), Pesquisa qualitativa com texto, imagem e som: Um manual prático (pp. 189-217). Vozes.

Black, J. R., Bailey, C., Przewrocka, J., Dijkstra, K. K., \& Swanton, C. (2020). COVID-19: The case for health-care worker screening to prevent hospital transmission. The Lancet, 395, 1418-1420. https://doi.org/10.1016/S0140-6736(20)30917-X.

Casalegno, F. (2006). Entrevista com Serge Moscovici - Memórias, rituais e ciber-representações. In F. Casalegno, Memória cotidiana: Comunidade e comunicação na era das redes (pp. 70-83). Sulina.

Gelfert, A. (2018). Fake News: A definition. Informal Logic, 38, 84-117. https://informallogic.ca/index.php/informal_logic/article/view/5068/4350.

Guimelli, C. (2003). Le modèle des schèmes cognitifs de base: Méthodes et applications. In J.-C. Abric (Ed.), Méthodes d'étude des représentations sociales (pp. 119-143). Ramonville Saint-Agne: Érès.

Hellewell, J., Abbott, S., Gimma, A., Bosse, N. I., Jarvis, C. I., Russell, T. W., \& Funk, S. (2020). Feasibility of controlling COVID-19 outbreaks by isolation of cases and contacts. The Lancet Global Health, 8, 488-496. https://doi.org/10.1016/S2214-109X(20)30074-7.

Li, R., Pei, S., Chen, B., Song, Y., Zhang, T., Yang, W., \& Shaman, J. (2020). Substantial undocumented infection facilitates the rapid dissemination of novel coronavirus (SARS-CoV-2). Science, 368, 489-493. https://doi.org/0.1126/science.abb3221. 
Research, Society and Development, v. 10, n. 7, e21110716266, 2021

(CC BY 4.0) | ISSN 2525-3409 | DOI: http://dx.doi.org/10.33448/rsd-v10i7.16266

Mazzotti, A. J. A., \& Campos, P. H. F. (2011). Cibercultura: uma nova "era das representações sociais"? In A. M. O. Almeida, M. F. S. Santos \& Z. A. Trindade (Orgs.), Teoria das Representações Sociais: 50 anos (pp. 457-488). Brasília: TechnoPolitik Editora.

Ministério da Saúde. (2020). Secretaria de Vigilância em Saúde (SVS/MS). Painel Coronavírus. Retrieved from https://covid.saude.gov.br

Moscovici, S. (2009). Representações Sociais: Investigações em psicologia social. Vozes.

Moscovici, S. (2012). A psicanálise, sua imagem e seu público. Vozes.

Mukerji, N. (2018). What is Fake News? Ergo, 5, 923-946. https://doi.org/10.3998/ergo.12405314.0005.035.

Neto, M., Gomes, T., Porto, F., Rafael, R., Fonseca, M., \& Nascimento, J. (2020). Fake news no cenário da pandemia de Covid-19. Cogitare enfermagem, 25. http://dx.doi.org/10.5380/ce.v25i0.72627.

Nicola, M., Alsafi, Z., Sohrabi, C., Kerwan, A., Al-Jabir, A., Iosifidis, C., ... \& Agha, R. (2020). The Socio-Economic Implications of the Coronavirus and COVID-19 Pandemic: A Review. International Journal of Surgery, 1-24. http://dx.doi.org/10.1016/j.ijsu.2020.04.018

Rouquette, M.-L. (1975). Les rumeurs. PUF.

Rouquette, M.-L. (1991). Rumeurs. In Grand dictionnaire de la Psychologie. Larousse, 683-684.

Rouquette, M.-L. (1994). Chaînes magiques, les maillons de l'appartenance. Delachaux et Niestlé.

Rouquette, M.-L. (1998). La communication sociale. Dunod.

Sá, C. P. (1996). Núcleo central das representações sociais. Vozes.

Schulz, A., Wirth, W., \& Müller, P. (2020). We are the people and you are fake news: A social identity approach to populist citizens' false consensus and hostile media perceptions. Communication Research, 47, 201-226. https://doi.org/10.1177/0093650218794854

Shimizu, K. (2020). 2019-nCoV, fake news, and racism. The Lancet, 395, 685-686. https://doi.org/10.1016/S0140-6736(20)30357-3

We Are Social \& Hootsuite (2020). Digital 2020 Brazil. https://datareportal.com/reports/digital-2020-brazil

World Health Organization (2020a). Rolling updates on coronavirus disease (COVID-19). https://www.who.int/emergencies/diseases/novel-coronavirus2019/events-as-they-happen.

World Health Organization (2020b). Coronavirus disease (COVID-19) pandemic. https://www.who.int/emergencies/diseases/novel-coronavirus-2019.

Zarocostas, J. (2020). How to fight an infodemic. World Report. The Lancet, 395, 676. https://doi.org/10.1016/S0140-6736(20)30461-X 